\title{
Effects of Split Weaning on the Performance of Hampshire Piglets
}

\author{
Arunima Kalita ${ }^{1}$, Raj Jyoti Deka ${ }^{1 "}$, Jogi Raj Bora ${ }^{1}$, Adib Haque ${ }^{1}$, Ankur Das $^{2}$ and Gunaram Saikia ${ }^{3}$ \\ ${ }^{1}$ Department of Livestock Production and Management, CVSc, AAU, Khanapara, Assam, INDIA \\ ${ }^{2}$ Department of Livestock Products Technology, CVSc, AAU, Khanapara, Assam, INDIA \\ ${ }^{3}$ Department of Animal Nutrition, CVSc, AAU, Khanapara, Assam, INDIA \\ *Corresponding author: RJ Deka, E-mail: rajsird09@gmail.com
}

Received: 16 July, 2021

Revised: 17 Sept., 2021

Accepted: 22 Sept., 2021

\begin{abstract}
The investigation was carried out under the Department of Livestock Production and Management, College of Veterinary Science, Assam Agricultural University, Khanapara, Guwahati-22. Forty eight piglets of Hampshire pig of three weaning age groups from six sows, considering an average litter size of 8 were selected for the experiment. Two groups (Group I and II) were split weaned at $28^{\text {th }}$ and $35^{\text {th }}$ days of age where 50 per cent of higher body weight piglets of the litter were separated and rest 50 per cent were kept with mother up to 56 days of conventional weaning. Another litter was weaned as conventional weaning age, 56 days (Group III). After weaning, the piglets were reared up to 75 days for studying of post weaning effect. The average body weight gain and total body weight was found to be higher in Group II and was found significantly higher followed by Group III and Group I while, the corresponding results was also observed in respect to the average daily, total and final body weight gain. In regards to the average total feed consumption, feed consumption by per piglet, feed consumption by per piglet per day and total feed consumed till end of the experiment period was more or less equal; the feed conversion efficiency was found to be comparatively higher in Group II than Group I and III.
\end{abstract}

\section{HIGHLIGHTS}

(0) The study focused on the effect of split weaning on growth of piglets.

0 Split weaning facilitates growth and helps in efficient feed conversion.

Keywords: Split weaning, Body weight, Feed consumption

Livestock production has long been the subsidiary occupation to agriculture in India. Among the livestock, pig is playing an important role in the socio-economic life of the rural community in the country as the piggery enterprise is still in the hands of traditional pig keepers who belong to the low socio-economic status without any good foundation stock, proper housing, feeding and management and also lacking of know-how on scientific management of pig. Like other parts of the country, the animal husbandry is an integral part of economy of NorthEastern Region; however, the livestock productivity is comparatively low. Among the meat producing animals, pig occupies a unique position in the region since its rearing in socio-culturally intermingled with livelihood of tribal folk.
The total pig population of India is estimated to be 9.06 million while Assam contributes about 2.10 million and ranks first in the country (20 ${ }^{\text {th }}$ Livestock Census). According to ICMR recommendation, out of 60 gm daily protein requirement; $20 \mathrm{gm}$ should be from animal protein source compared to the present availability of only $10 \mathrm{gm}$ from animal protein. The share of pork is around 8 per cent of total meat production in India. The major aim in any swine enterprise is to increase the pork and pork product

How to cite this article: Kalita, A., Deka, R.J., Bora, J.R., Haque, A., Das, A. and Saikia, G. (2021). Effects of Split Weaning on the Performance of Hampshire Piglets. J. Anim. Res., 11(05): 825-830.

Source of Support: None; Conflict of Interest: None क्) 
through scientific management of pig and to reduce the mortality loss. However, failure of pig rearing in India is mainly due to mortality of pig, more particularly in pre weaning period.

Weaning of piglets is an important operation in piggery farms to maintain health status of sows and piglets. Weaning is the stage that comes after lactation, in which the piglets are taken away from their dam and normally proceed to eat only solid food and water. Usually weaning of piglet is done in India at 8 weeks of age. But early weaning is also practiced to obtain some advantages like rebred of sow early and to lessen the weight loss of the sow during lactation. There is a complete control of nutrient supply to the pig in early weaning; pigs are more uniform, heavier and healthier and better control of the diseases in the herd is possible (Suryanarayana and Suresh, 2011). Split weaning is another means of weaning piglets where not all the piglets of the litter are weaned at the same time and leave some of them with their dam for an extra period of time. This allows smaller piglets continued access to the sow for another sometime. Any practice, which maintains litter size and reduces the interval between weaning and mating for early weaned sow, should significantly improve pig productivity (Ravi et al., 2013). Appropriate feeding and nutrition strategies, management practices and animal welfare activities, bio-security and disease prevention measures are critical determinants of gut health and piglet performance.

\section{MATERIALS AND METHODS}

The experiment was carried out at the 30-Sow Teaching Unit under the Department of Livestock Production and Management, College of Veterinary Science, Assam Agricultural University, Khanapara, Guwahati - 781022. A total of 48 piglets of Hampshire pig of three weaning age groups from six sows, considering an average litter size of 8 were selected for the experiment. The piglets were divided into three groups consisting of 16 piglets in each group. Two groups (Group I and II) were split weaned at $28^{\text {th }}$ and $35^{\text {th }}$ days of age where $50 \%$ of heavy piglets of the litter were separated and rest $50 \%$ were remained with mother up to 56 days of conventional weaning. The another litter was weaned as conventional weaning age, 56 days (Group III) to compare with the split weaning on growth performance and feed intake of the piglets. After weaning, the piglets were reared up to 75 days for studying of post weaning effect. During the experimental period, the piglets along with the mother were housed in conventional housing system at 30-Sow Teaching Unit Farm, College of Veterinary Science, Guwahati. After farrowing, the sow and her piglets were reared in the farrowing pen till weaning. Split weaned piglets of Group I and Group II were housed adjacent to the respective mother's pen with minimum disturbances. Finally, sows were separated from the farrowing pen to dry pen after 56 days of farrowing and piglets were kept in the same pen up to 75 days. All pens were washed and disinfected every day.

At the initiation of the experiment, piglets were raised with mother's milk up to 14 days of age. The creep ration was provided from $14^{\text {th }}$ day onward to $56^{\text {th }}$ days of age and then, grower ration was offered till $75^{\text {th }}$ days of age. The experimental piglets were fed in group. The daily requirement of ration was divided into two equal halves and offered in the morning and evening. Likewise, sows of all groups were fed to appetite on a lactation diet during the lactation period. The pigs were provided with clean and wholesome water round the clock throughout the experiment.

The individual body weights of piglets for all the groups were recorded from birth of piglets and subsequent body weight of the piglets were recorded at weekly interval till 75 days of age. The total and daily body weight gain was also recorded. The data were statistically analyzed by using design of CRD in SAS 9.3 (2013).

The creep and grower ration was formulated to meet the nutrient requirement recommended by NRC (1998) with the following formula (Table 1):

Table 1: Composition of creep ration and grower ration

\begin{tabular}{lll}
\hline Ingredients & Creep Ration (\%) & Grower Ration (\%) \\
\hline Maize & 60 & 50 \\
Wheat Bran & 9 & 22 \\
Groundnut cake & 20 & 20 \\
Fish meal & 8 & 5 \\
Mineral mixture & 2.5 & 2 \\
Common salt & 0.5 & 1 \\
\hline Total & $\mathbf{1 0 0}$ & $\mathbf{1 0 0}$ \\
\hline
\end{tabular}

Vitamin@25g/quintal (Sharkoferol). 
The proximate composition of the individual ingredient was estimated as per method described by AOAC (2005).

Table 2: Proximate compositions of the feed ingredients

\begin{tabular}{llllll}
\hline & \multicolumn{5}{c}{ Proximate composition (\%) } \\
\cline { 2 - 6 } Ingredients & Moisture & $\begin{array}{l}\text { Crude } \\
\text { Protein }\end{array}$ & $\begin{array}{l}\text { Crude } \\
\text { Fiber }\end{array}$ & $\begin{array}{l}\text { Ether } \\
\text { Extract }\end{array}$ & $\begin{array}{l}\text { Total } \\
\text { Ash }\end{array}$ \\
\cline { 2 - 6 } Creep & $10.16 \pm$ & $19.75 \pm$ & $4.85 \pm$ & $4.56 \pm$ & $5.75 \pm$ \\
ration & 0.02 & 0.31 & 0.16 & 0.05 & 0.10 \\
Grower & $10.24 \pm$ & $18.56 \pm$ & $5.15 \pm$ & $3.96 \pm$ & $5.22 \pm$ \\
ration & 0.03 & 0.26 & 0.21 & 0.02 & 0.06 \\
\hline
\end{tabular}

\section{RESULTS AND DISCUSSION}

\section{Growth Performance}

The average initial body weights of the piglets were found to be $1.18 \pm 0.04,1.22 \pm 0.04$ and $1.12 \pm 0.03 \mathrm{~kg}$ for Group I, II and III, respectively and no significant difference was found. Similar findings were reported by Suryanarayana and Suresh (2011), Kalita (2012). Higher birth weight was observed by Skorjanc et al. (2007) in Landrace and Kalita et al. (2015) in LWY while lower than the present findings were mentioned by Ranjan et al. (2003) in T\&D pigs. These differences in body weight at birth recorded by different workers with the present findings might be due to differences in breed, feeding, environmental conditions and other managemental practices.

The average weaning body weight of piglets at day 28 , 35,56 and 75 were recorded as $5.72 \pm 0.10,6.71 \pm 0.14$, $9.97 \pm 0.23$ and $13.54 \pm 0.33 \mathrm{~kg}$ for Group I, $6.59 \pm 0.14$, $7.94 \pm 0.13,12.35 \pm 0.21$ and $16.19 \pm 0.21 \mathrm{~kg}$ for Group II and $6.09 \pm 0.13,7.54 \pm 0.11,11.34 \pm 0.19$ and $14.74 \pm 0.20 \mathrm{~kg}$ for Group III while the body weight gain was calculated as $4.54 \pm 0.09,5.53 \pm 0.138 .79 \pm 0.22$ and $12.36 \pm 0.33 \mathrm{~kg}$, $5.37 \pm 0.13,6.72 \pm 0.12, \quad 11.13 \pm 0.20$ and $14.97 \pm 0.19 \mathrm{~kg}$ and $4.99 \pm 0.13,6.42 \pm 0.11,10.22 \pm 0.20$ and $13.62 \pm 0.19$ $\mathrm{kg}$ for respective group. Group II was significantly higher $(\mathrm{P}<0.01)$ than Group I, but did not differ from Group III, while Group III and I did not differ from each other. These findings were in agreement with those of similar weaning weight at 28, 35, 56 and 75 days of age was observed by Rava (1991) in Hampshire pigs, Roychoudhury (1990) in Landrace piglets, Kalita (2012) in T\&D pigs. While the lower weaning weight at 28, 35, 56 and 75 days was reported by Roychoudhury (1978) in Landrace piglets, Gupta et al. (2001) in 75\% LWY, 50\% LWY and Desi, Sudhakar and Gaur (2003) in Indigenous, Cauveri et al.(2009) in 75\% LWY and 50\% LWY, Kharpran (2014) in Hampshire, Tissopi (2018) in Hampshire piglets, Devendran et al. (2015) in LWY (50\%), Lalremruata et al. (2015) in Burmese pigs, Khatun (2018) in Hampshire x Indigenous, Phookan (2008) who got 13.792 and 14.142 $\mathrm{kg}$ at $12^{\text {th }}$ week in $50 \%$ and $70 \%$ Hampshire pigs and Pandey and Singh (2010) found $12.58 \pm 0.57 \mathrm{~kg}$ in Landrace pigs. Whereas higher values were reported by Fraser et al. (1994) in Landrace $\times$ LWY, Mili (1995) in Hampshire, Narayanan et al. (2008) in LWY and Toi (2017) in Hampshire pigs. Differences in body weight recorded by different workers with the present findings might be due to differences in breed, feeding, environmental conditions, type of ration and other managemental practices.

The average daily body weight gain from initial to 75 days of post weaning experimental period was $0.165 \pm 0.004$, $0.200 \pm 0.002$ and $0.182 \pm 0.002 \mathrm{~kg}$ in Group I, II and III, respectively. Group II was significantly higher $(\mathrm{P}<0.01)$ than Group I, but did not differ from Group III, while Group III and I did not differ from each other. Similar findings were reported by Ferdoci (2001) in Hampshire (H), $1 / 2 \mathrm{H} \times$ $1 / 2$ Saddle Back and $3 / 4 \mathrm{H} \times 1 / 4$ Saddle Back pigs from birth to $8^{\text {th }}$ week and $8^{\text {th }}$ to $16^{\text {th }}$ week, respectively. The reports on average daily gain found to be lower than the present findings as reported by Banik et al. (2013) in 'Ghungroo' and 'Niang Megha' pigs and Ganesan et al. (2013) in Large White Yorkshire-Desi crossbred pigs. Contrary to the present findings, higher values of average daily gain were reported by Fahmy (1970) in three different lines of Yorkshire pigs and Sravanthi (2014). The differences in findings of lower and higher body weight gain might be attributed to different weaning age, breeds and place of investigation towards the present investigation.

The graphical representations of the data on the weekly body weight gain of Hampshire piglets on split weaning reared on conventional housing system have been depicted in Fig. 1. From the graph, it was clearly indicated that there was maximum increasing tendency of body weight gain from 2nd week onward for the Group II and III compared to Group I while maximum gain was observed in Group II till end of the experiment. 
Table 3: Average body weight gain $(\mathrm{kg})$ of split weaned Hampshire piglets

\begin{tabular}{|c|c|c|c|c|c|c|}
\hline \multirow{2}{*}{ Group } & \multirow{2}{*}{ Initial Weight } & \multicolumn{3}{|c|}{ Weaning Body weight Gain } & \multirow{2}{*}{$\begin{array}{l}\text { Final Weight } 75 \\
\text { days }\end{array}$} & \multirow{2}{*}{ Total Weight Gain } \\
\hline & & 28 days & 35 days & 56 days & & \\
\hline G I & $1.18 \pm 0.04$ & $4.54^{\mathrm{a}} \pm 0.09$ & $5.53^{\mathrm{a}} \pm 0.13$ & $8.79^{a} \pm 0.22$ & $13.54^{\mathrm{a}} \pm 0.33$ & $12.36^{\mathrm{a}} \pm 0.33$ \\
\hline G II & $1.22 \pm 0.04$ & $5.37^{b} \pm 0.13$ & $6.72^{\mathrm{b}} \pm 0.12$ & $11.13^{\mathrm{b}} \pm 0.20$ & $16.19^{\mathrm{b}} \pm 0.21$ & $14.97^{\mathrm{b}} \pm 0.19$ \\
\hline G III & $1.12 \pm 0.03$ & $4.99^{\mathrm{ab}} \pm 0.13$ & $6.42^{\mathrm{ab}} \pm 0.11$ & $10.22^{\mathrm{ab}} \pm 0.20$ & $14.74^{\mathrm{ab}} \pm 0.20$ & $13.62^{\mathrm{ab}_{ \pm}} \pm 0.19$ \\
\hline
\end{tabular}

Means in column with common superscripts do not differ significantly.

Table 4: Average feed consumption and feed conversion efficiency (on dm basis) of split weaned Hampshire piglets

\begin{tabular}{|c|c|c|c|c|c|c|}
\hline \multirow{2}{*}{ Group } & \multicolumn{3}{|c|}{ Total feed consumed (kg) } & \multirow{2}{*}{$\begin{array}{l}\text { Total feed } \\
\text { consumed till } 75 \\
\text { days }(\mathrm{kg})\end{array}$} & \multirow{2}{*}{$\begin{array}{l}\text { Total body } \\
\text { weight gain per } \\
\text { piglet }(\mathrm{kg})\end{array}$} & \multirow{2}{*}{$\begin{array}{l}\text { Feed conversion } \\
\text { efficiency }\end{array}$} \\
\hline & 28 days & 35 days & 56 days & & & \\
\hline G I & 10.46 & 18.18 & 38.47 & 287.85 & $12.36 \pm 0.33$ & 1.46 \\
\hline G II & 10.34 & 18.15 & 38.29 & 287.08 & $14.97 \pm 0.19$ & 1.20 \\
\hline G III & 10.15 & 17.86 & 38.36 & 285.29 & $13.62 \pm 0.19$ & 1.31 \\
\hline
\end{tabular}

\section{Feed Consumption}

The average total feed consumed (on dry matter basis) by Group I, II and III was recorded as 10.46, 10.34 and 10.15; $18.18,18.15$ and 17.86 , and $38.47,38.29$ and $38.36 \mathrm{~kg}$ for piglets weaned at 28,35 and 56 days, respectively. In the corresponding groups and weaning age, the average total feed consumed by per piglet was calculated as $0.60,0.65$ and $0.63 ; 1.14,1.13$ and 1.12 , and $2.40,2.39$ and $2.40 \mathrm{~kg}$ while the average total feed consumed by per piglet per day was worked out and found same in every group as 0.04 , 0.07 and $0.15 \mathrm{~kg}$ for piglet weaned at 28, 35 and 56 days. Overall, the average total feed consumed by the piglets of Group I, II and III till the end of the experiment (75 days) was computed $287.85,287.08$ and $285.29 \mathrm{~kg}$, respectively. From the findings of the present study revealed that more or less same quantities of feed consumed by all the groups in respect to the total feed intake, average total feed consumed by per piglet, average total feed consumed by per piglet per day and the average total feed consumed till the end of the experiment ( 75 days).

Similar finding to the present study was reported by Rava (1991). Higher average daily feed intake than the present findings were reported by Toi (2017) in Hampshire pigs and Tissopi (2018) in Hampshire. The differences in findings might be due to different in technical program and other environmental conditions at the time of experiment.

\section{Feed Conversion Efficiency}

Feed conversion efficiency can be defined as unit of feed consumed per unit gain in body weight. It is generally used as an index to determine the productive efficiency of piglets. The feed conversion efficiency for the different weaned piglets was observed best in Group II (1.20) followed by Group III (1.31) and Group I (1.46). The feed conversion efficiency of Group II was the highest among the three groups.

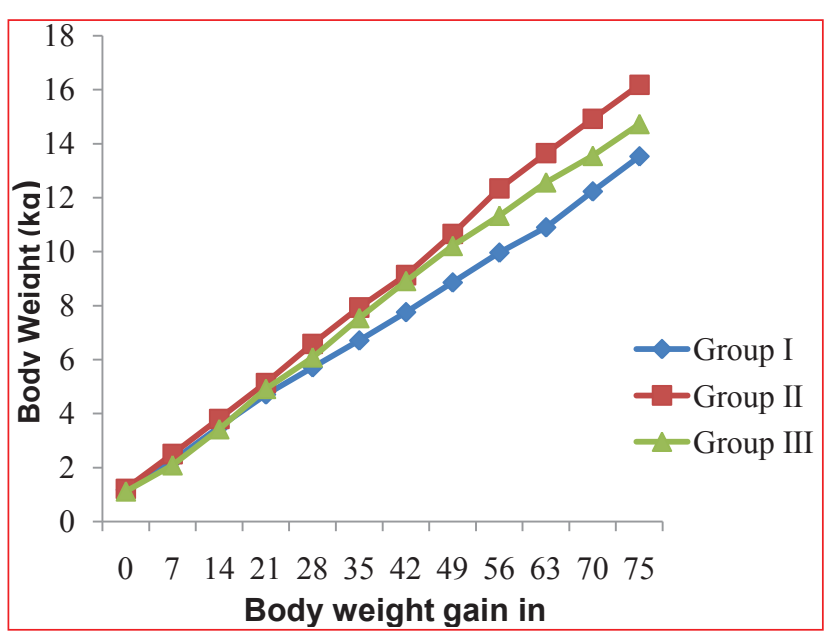

Fig. 1: Body weight gain of split weaned Hampshire piglets

More or less similar trend on feed conversion efficiency was reported by Marwein (2008) in Hampshire crossbred 
piglets and Kharpran (2014). A lower feed conversion efficiency than the present result was found by Indupalli (2016) and Tissopi (2018). The feed conversion efficiency might be attributed in differences methodology of experiment, breeds and agro-climatic conditions.

The graphical representation of average weekly feed consumption $(\mathrm{kg})$ on dry matter basis of split weaned at 28, 35, 56 days of Hampshire piglets (Fig. 2) revealed slight variation on feed consumption among the three groups from $3^{\text {rd }}$ weeks of age to end of the experiment i.e. 75 days. However, the feed consumption was found to be higher in Group I followed by Group III and II.

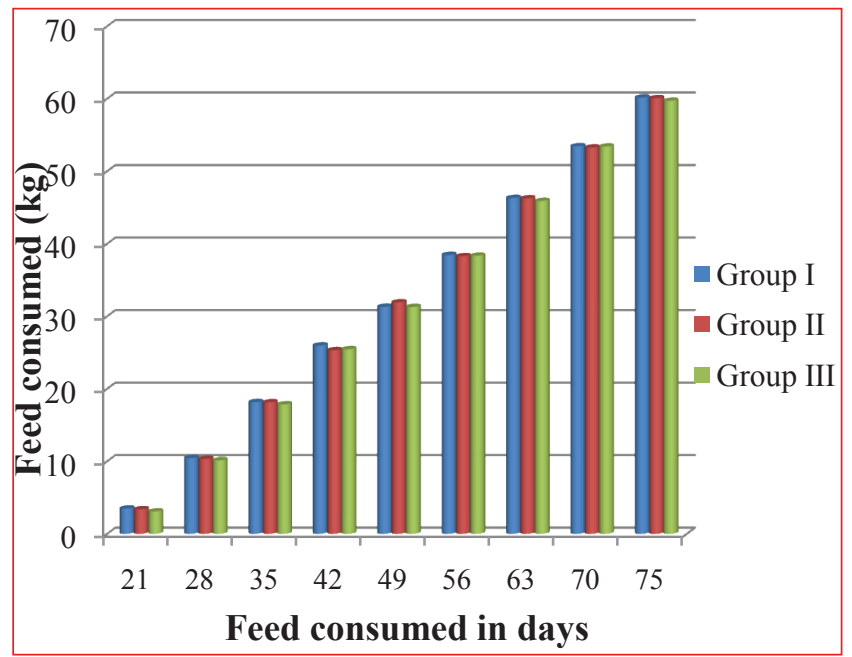

Fig. 2: Average weekly feed intake $(\mathrm{kg})$ on $\mathrm{dm}$ basis of split weaned Hampshire piglets

\section{CONCLUSION}

From the present study it may be concluded that the overall productive performances in respect to growth and feed conversion efficiency of Hampshire piglets were found better in piglets split weaned at 35 days of age (Group II) followed by piglet split weaned at 56 days of age (Group III) and comparatively poor in piglets split weaned at 28 days of age (Group I). In general, strategies that increase weaning weight may have a greater impact on overall pig performance than feeding and management strategies that aim to accelerate growth rate immediately after weaning.

\section{CONFLICT OF INTEREST}

There is no conflict between the authors regarding the preparation of the manuscript. The research was carried out as a part of fulfillment of M.V.Sc. Degree Programme. All authors contributed to the research woks and members of the research advisory committee. All authors read and approved the final manuscript.

\section{ETHICS APPROVAL}

The research was carried out according to the guidelines of Institutional Animal Ethics Committee of Assam Agricultural University, Khanapara, Guwahati-781022 as per the ethics application approval number $770 / \mathrm{GO} /$ Re/S/03/CPCSEA/FVSc/AAU/IAEC/18-19/654 dated 28.12.2018.

\section{ACKNOWLEDGEMENTS}

The authors are thankful to Department of Livestock Production and Technology, Assam Agricultural University, Khanapara-781022 to carry out the research work.

\section{REFERENCES}

Anonymous, 2019. 20 ${ }^{\text {th }}$ Livestock Census-2019, All India Report. Ministry of Fisheries, Animal Husbandry and Dairying, Animal Husbandry Statistics Division, Krishi Bhawan, New Delhi.

AOAC, 2005. Official Methods of Analysis. $8^{\text {th }}$ Edn., Association of Analytical Chemists, Gaithersburg MD.

Banik, S., Naskar, S., Pankaj, P.K., Pourouchottamane, R., Barman, K., Sahoo, N.R. and Tamuli, M.K. 2013. Construction of growth band for early selection of indigenous pigs in India. Appl. Biol. Res., 15(1): 73-77.

Cauveri, D., Sivskumar, T. and Devendran, P. 2009. Pre-weaning body weights in Large White Yorkshire Crosses. Indian J. Anim. Res., 43(2): 130:132.

Devendran, P., Gopinathan, A., Murugan, M. and Cauveri, D. 2015. Pre-weaning body weights of Large White Yorkshire (50\%) pig crosses over generation. Indian J. Anim. Res., 49(3): 284-287.

Fahmy, M.H. and Bernard, C. 1970. Genetic and phenotypic study of pre-and post-weaning weights and gains in swine. Can. J. Anim. Sci., 50(3): 593-599.

Ferdoci, A.M., 2001. Genetic evaluation of exotic pigs and their crossbred in respect of certain growth and reproductive traits. Ph.D. Thesis. Assam Agricultural University, Khanapara, Guwahati- 22, Assam. 
Fraser, D., Fedded, J.J.R. and Pajor, E.A. 1994. The relationship between creep feeding behavior of piglets and adaptation to weaning: Effect of diet quality. Can. J. Anim. Sci., 74: 1-6.

Ganesan, R., Dhanavanthan., Kiruthika., Kumarasamy, P., Murugan, M. and Jaishankar, S. 2013. Factors influencing growth performance and estimation of genetic parameters in crossbred pigs. J. Agric. Vet. Sci., 5: 63-71.

Gupta, R.K., Singh, V.P. and Belsare, V.P. 2001. Growth pattern and mortality in pre-weaning crossbred pigs. Indian J. Anim. Res.,35(2): 96-99.

Indupalli, R. 2016. Effect of early and split weaning on performance and behavior of Large White Yorkshire piglets. M.V.Sc. Thesis. NTR College of Veterinary Science, Sri Venkateswara Veterinary University, Tirupati- 517502.

Kalita, G. 2012. Performance of T\&D pigs under different weaning management. Ph.D. Thesis. Assam Agricultural University, Khanapara, Guwahati-22, Assam.

Kalita, G., Buragohain, R., Saikia, P., Sarma, K. and Rahman, S. 2015. Effect of Weaning Age on growth Performance and Feed Conversion Efficiency of Large White Yorkshire (LWY) Piglets under Intensive System of Management in Mizoram. Int. J. Sci. Res., 4(1): 90-94.

Kharpran, S. 2014. Performance of pre-weaned Hampshire piglets fed with dietary supplementation of dried brewing yeast. M.V.Sc. Thesis. Assam Agricultural University, Khanapara, Guwahati-22, Assam.

Khatun, M. 2018. Genetic studies on growth performance and polymorphism of IGF-II and POU1F1 genes in crossbred pigs. M.V.Sc. Thesis. Assam Agricultural University, Khanapara, Guwahati-22, Assam.

Lalremruata, C., Hmar, L. and Kalita, G., 2015. Study on the growth performance and mortality in pre-weaning Burmese piglets reared under field condition of Aizawl, India. Indian J. Anim. Res., 49(2): 262-264.

Marwein, N. 2008. Performance of crossbred piglets fed on de-oiled rice bran based diet during pre-weaning period. M.V.Sc. Thesis. Assam Agricultural University, Khanapara, Guwahati-22, Assam.

Mili, D.C. 1995. Effect of age at castration on the growth rate and weight at slaughter on carcass yield and certain meat quality characteristics of Hampshire pigs. Ph.D. Thesis. Assam Agricultural University, Khanapara, Guwahati-22, Assam.

Narayanan, R., Ronald, B.S.M., Baegan, S. and Prabakaran, R., 2008. Effect of age at weaning on growth performance of Large White Yorkshire. Tamil Nadu J. Vet. Anim. Sci., 4(6): 237-239.

National Research Council, 1998. Nutrient Requirements of Swine. $10^{\text {th }}$ Rev. Edn. The National Academic Press, Washington DC.
Pandey, A. and Singh, S. K. 2010. Factors affecting body weight in landrace, desi and their halfbred pigs. Int. J. Mole. Biol., 1(1): 21-24.

Phookan, A. 2008. Trend in the performance of crossbred pigs with 50 and 75 per cent Hampshire inheritance. Ph.D Thesis. Assam Agricultural University, Khanapara, Guwahati-22, Assam.

Ranjan, R., Singh, S.K. and Singh, S.S. 2003. Growth performance on different feeding and rearing practices in pig. Indian J. Anim. Sci., 73(2): 194-196.

Rava, S., 1991. Effect of skim milk feeding and early weaning on the growth performance of Hampshire pigs. M.V.Sc. Thesis. Assam Agricultural University, Khanapara, Guwahati-22, Assam.

Ravi, P., Pandey, H. N., Porteen. N. and Selvaraju. G. 2013. Effect of early and split weaning performance on crossbred gilts (Landrace $\times$ Desi). Indian J. Vet. Res., 22(1): 32-37.

Roychoudhury, R. 1978. Studies on pre-weaning growth and its effect on subsequent body weight gains in Landrace pigs. M.V.Sc. Thesis. Assam Agricultural University, Khanapara, Guwahati-22, Assam.

Roychoudhury, R. 1990. Some managemental aspects of pre-weaning piglets. Ph.D. Thesis. Assam Agricultural University, Khanapara, Guwahati-22, Assam.

Sapra, K.L. and Shingari, B.K. 1991. Effect of feeding livol on growth in turkey. Indian J. Indg. Med., 8(1): 96.

SAS. 2013. Enterprise Guide 9.3.

Skorjanc, D., Brus, M. and Candek Potokar, M. 2007. Effect of Birth Weight and Sex on Pre-Weaning Growth Rate of Piglets. Arch. Anim. Breed., 50: 476-486.

Sravanthi, V. 2014. Influence of early weaning on the production and reproduction performance and behavior of Large White Yorkshire. M.V.Sc. Thesis. NTR College of Veterinary Science, Sri Venkateswara Veterinary University, Tirupati517502.

Sudhakar, K. and Gaur, G.K. 2003. Preweaning growth in indigenous pigs of eastern region. Indian J. Anim. Sci.,73(10): 1182-1183.

Suryanarayana, M.V.A.N and Suresh, J. 2011. Effect of early weaning on behavioral patterns in piglets. Tamilnadu J. Vet. Anim. Sci., 7(3): 133-136.

Tissopi, M. 2018. Effect of feeding milk powder and probiotics supplemented feed on growth performance, feed consumption and physiological response in pre-weaned piglets. M.V.Sc. Thesis. Assam Agricultural University, Khanapara, Guwahati-22, Assam.

Toi, S.M.L. 2017. Effect of feeding solid state fermented ration on the performance of Hampshire piglets. M.V.Sc. Thesis. Assam Agricultural University, Khanapara, Guwahati-22, Assam. 